\title{
Parenthood and Paid Work: Conflict, Compromise and Compatibility
}

\author{
Heather Joshi \\ UCL-Institute of Education, Centre for Longitudinal Studies \\ h.joshi@ucl.ac.uk
}

\begin{abstract}
:
The paper opens with an illustration of how successive generations of women in my own family have combined motherhood and paid employment since the end of the Nineteenth Century in Britain: an exceptionally wellqualified line of women, fitting in to the dominant male breadwinner norm, enshrined in Beveridge's National Insurance system. I then turn to the general idea that the employment of women came to be viewed as relevant to population studies, in particular. Improvements in women's economic opportunities were seen as helping to bring down the number of births, both in high fertility and low fertility societies. A key idea was that better prospects in the female labour market would raise the opportunity cost of motherhood. This story does not quite fit the experience of post war Britain, where women's employment has been rising, sometimes at the same time as fertility. The latter has fluctuated but is still relatively high by international standards. Motherhood was increasingly combined with employment, though paid work was often part-time, secondary to that of the male breadwinner. This compromise contributed to maintaining the gap in pay between men and women, especially given the a-symmetric pay differentials of fathers and mothers. Paradoxically the future of fertility in industrial countries is no longer seen by demographers as necessarily depending on sustaining female subordination. An alternative would be improving the terms on which both men and women can combine paid work with parenthood. Just as paid work need not be a sphere where women occupy a secondary place, the role of men as giving care within the family could be developed. Parenthood is taking increasingly diverse forms in the $21^{\text {st }}$ century, and egalitarian childrearing has the potential to provide better prospects for the next generation.
\end{abstract}

Keywords: Motherhood; women's earnings; fertility transition; opportunity cost; egalitarian parenthood; breadwinner 


\section{Introduction}

Improvements in women's economic opportunities have been assumed to compete with their role as mothers. I examine some evidence, mainly from Britain, of how the conflict of productive and reproduction roles has given way to compromise and compatibility, albeit constrained. Starting with some personal stories from four generations of women in my own family, I turn briefly to the connection between women's status and the fertility transition at a macro level. The paper then focuses on post war Britain where I review my research on the interrelationship of women's employment, childrearing and its opportunity cost. I move on to argue that social reproduction should also involve fathers' involvement in childrearing, with contemporary evidence from Europe.

A Tale of Three Grandmothers

Speakers sometimes introduce themselves so the audience can understand 'where they have come from'. I will start by introducing some of my female forebears. Though they are far from representative individuals (if anyone is), their lives illustrate the changing context of women's careers in Britain over the last century and a half.

My maternal great grandmother, Maria Agnes Boswell, was born in 1841, daughter of a London cabinet maker (Figure 1). She went to a teacher training college around 1860, quite unusual at that time, and set off to North Wales in 1864, to become headmistress of the girls' school in Conway. She met and married, in 1873, a post-office engineer from Devon who was bringing the telegraph to North Wales. They had a jolly wedding at which her pupils sang beautifully. Once married she never worked for pay again, she became a pillar of the community as well as the mother of five high achievers. Her eldest daughter Florence, my grandmother, was born in 1875 (Figure 2). She went to London in the 1890s to work as a secretary. She studied at evening classes at LSE in its early Fabian days. She was one of their first female graduates. By the time her BSc in economics was awarded, in 1905, she was 30 and had just married my grandfather. She did continue some paid work after her marriage - doing some 'boring' statistics for the young William Beveridge - but she left before her first child in 1908 and never had any formal employment since that. She was active with the suffragists and had another child, my mother Molly, in 1914. She did some occasional talks for children's radio, and from the age of 50 onwards became a prolific amateur watercolour painter, selling her 'sketches' for good causes. She was a saintly figure who lived into her nineties and my twenties. She envied the opportunities facing my generation, aware that her own had been limited.

Florence's daughter, Molly, was another high flyer - head girl of her school, scholarship to Cambridge and a PhD in Zoology - again very rare for a woman of her generation (Figure 3). She joined the war effort in a team devising anti-fouling paints for ships. She had met my father at the Marine Biological Laboratory in Plymouth before the war, and they married in 1943, while my father was on war service as a code-breaker. They moved back to Plymouth in 1945, but her professional life was interrupted for a very long time. She said that raising two small children was demanding enough, but there were other impediments. The Marine Laboratory had a rule against employing spouses, and her new mother-in-law was adamantly opposed to her daughter-in law 'going out to work'. Although she never ceased to be a scientist in mind-set, Molly was effectively a housewife for 23 years, looking after children, elders and a naturalists garden. She was drawn back to scientific work in 1967 at the time of the first super-tanker oil spill. It was all- hands- on-deck (or rather beaches and rocks) to study ways of dealing with coastal oil pollution. When my father and his colleagues resumed their previous work, Molly carried on working on oil. Her new expertise was much in demand, all around the world, and for advice the UK government. She got an MBE for this work (matching my father's for codebreaking) and chose to retire after a few years in this second career, to keep my father company. The local newspaper headline was 'Slick expert retires' but her personal style was far from slick. She took care of my father in his final illness, but kept active with wildlife conservation, watercolours and knitting till her own death in 1997.

As Molly's late flowering marine biological career was coming to an end, I was making faltering steps into the field of economics, marrying and then separating from an Indian economist whose surname I retain. My career did not really find a way forward until, in 1975, a job in the Government Economic Service introduced me to data on women's employment in Britain. Barbara Castle's reforms to women's pensions were being brought in to modernise the arrangements designed by William Beveridge in 1942 . I moved in 1979 to an academic setting - the interdisciplinary Centre for Population Studies at the London School of Hygiene and Tropical Medicine. I have spent the 41 years since then doing academic research, in various institutions, much of it concerned with gender. 


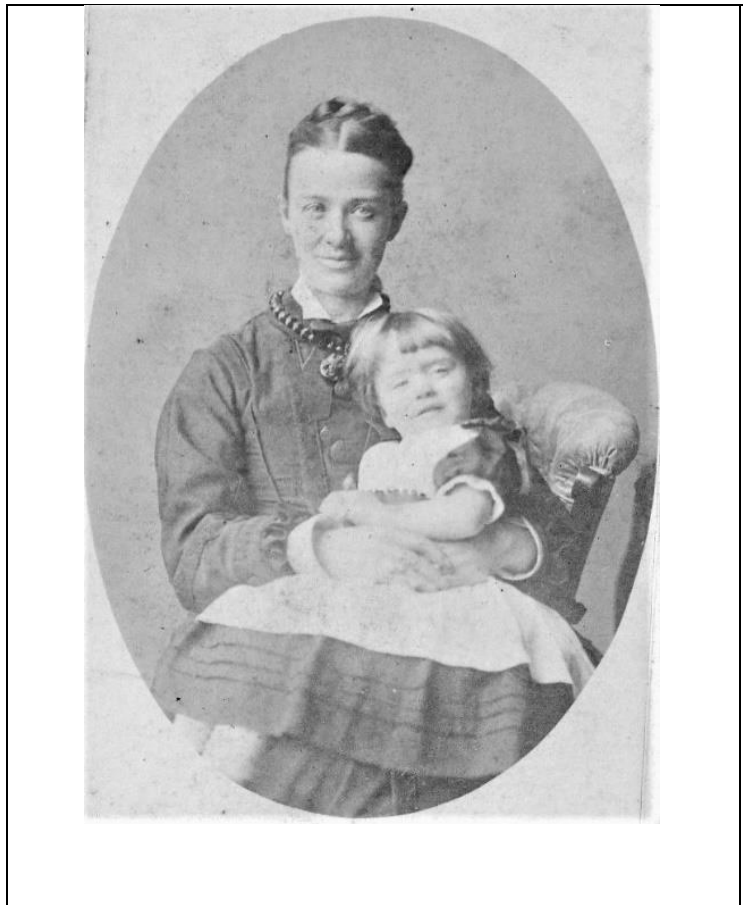

Figure 1

Maria Agnes Lee (née Boswell) 1841-1921, and Florence in 1878

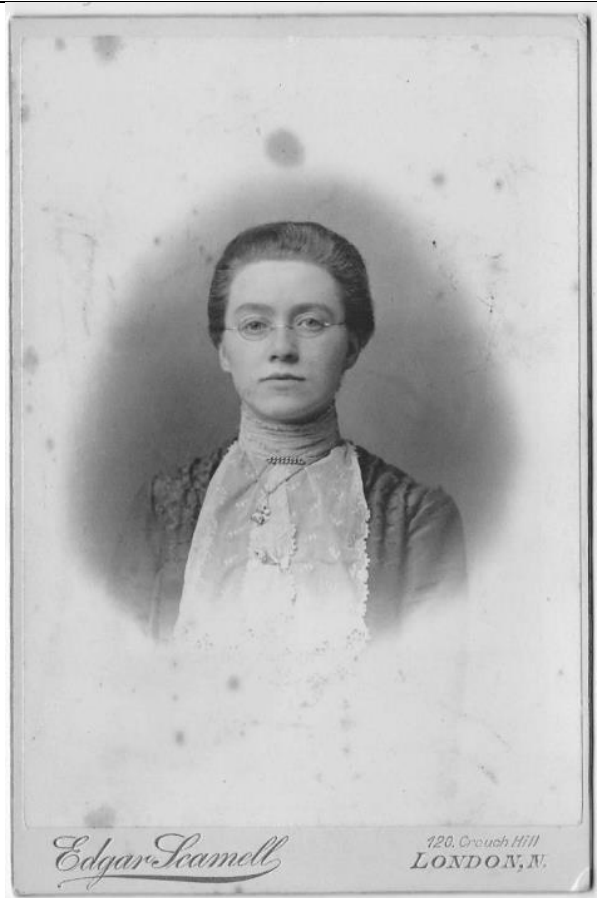

Figure 2

Florence Agnes Mare ( née Lee) 1875-1971

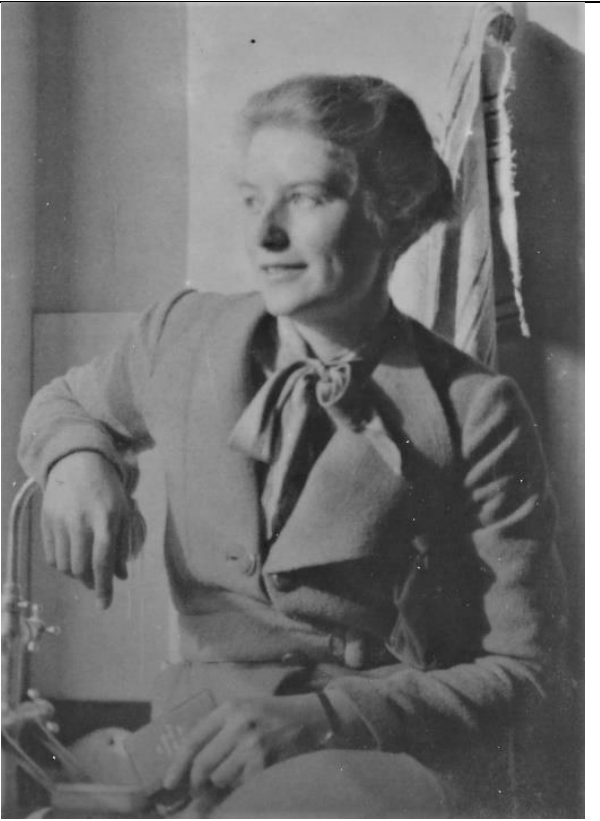

Figure 3

Dr Molly Florence Spooner (née Mare) 1914- 1997 


\section{Women's Status and the Fertility Transition}

In the 1960s and 1970s, despite the rise of feminism, gender issues hardly featured in the academic curriculum of social sciences. In demography, recognition was dawning that the empowerment of women might contribute to lowering high fertility (Kirk 1996). This would apply both historically in countries that had already undergone the 'transition' from high to low rates of mortality and fertility around the turn of twentieth century and in places still experiencing high fertility rates in the later part of that century. Better economic opportunities for women would offer an incentive to curtail childbearing. Motherhood has an 'opportunity cost' in terms of women's forgone earnings, which it could be rational to avoid (Becker, 1965). The simple economic model is not without limitations (Anker 1982). The assumption of an incompatibility of motherhood and productive work begs a number of question. What are the alternative sources of childcare? Who has power within household? What are the risks, including mortality, in the environment? What are the cultural norms about the value of children to whomever may be making the decision?. Women's disempowerment has many facets. It could be reflected in female disadvantage in education, paid work, property or political rights, a lack of autonomy in matters of marriage, divorce and childrearing, and perhaps preferences for sons. In some settings, women's lives are secluded. In others, whatever paid work is available is segregated and low paid. Paid work can have social and psychological benefits beyond the cash. Some 'stay-at-home mothers' suffer social isolation (classically described by Gavron, 1966). Gendered norms, expectations and behaviour are reinforced by violence against women and its toleration. Nevertheless employment outside the home may foster fertility limitation via the fostering of autonomy rather than the perception of forgone earnings (Piepmeier and Adkins, 1973).

For most of the second half of the twentieth century, population growth had been seen as a problem to be tackled by international policy to promote fertility reduction (Presser, 1997). The 1994 Cairo Declaration on Population and Development (UNPF 2014) made the unprecedented assertion that the empowerment and autonomy of women, with improvement of their political, social, economic and health status, were highly important ends in themselves. The Action Plan did state that women's empowerment was also essential for the achievement of sustainable development, implicitly fertility decline. Women's reproductive rights trumped birth control on the policy agenda and gender issues were established (if not universally welcome) in demographic studies. It also stated: 'The full participation and partnership of both women and men is required in productive and reproductive life, including shared responsibilities for the care and nurturing of children and maintenance of the household' a theme to which I will return.

There may not be consensus on whether improvements in 'women's status' have brought about the spectacular declines in fertility subsequently seen in much of the Global South which were so worrying to the neo Malthusians in the 1970s. Nor have these transitions necessarily improved the status and health of women in those countries. Any such relationships may have been mutually reinforcing and doubtless different in different places and social groups. The total period fertility rate summarizes current childbearing as the number of children the average woman would eventually bear if current rates at each age persist. The latest estimate for India in 2019 is 2.2 children per woman - a phenomenal fall from 5.9 in 1950-1964 and is now around the population replacement level (World Data Atlas, 2020), but female labour force participation, for example, remains low. The gender research community may judge how far this has been accompanied by a change in the 'status of women', in India or elsewhere.

\section{Trends in Family Formation in Britain}

The decline in fertility in the past half century in India is of a similar order of magnitude to Britain's first demographic transition: from around 5 children per woman in 1870 to around 2 in 1930 (Figure 4). Better education and more employment for single women may have helped raise age at marriage, indirectly reducing fertility, but in these years, married women's participation in paid work was low. In the nineteenth century there were forces raising the costs of children: the abolition of child labour and the extension of education. Rising costs of employing domestic servants may have put pressure on lower middle to upper class families to limit births (Coleman and Salt 1992, pp 66-72). The women's vote after World War 1 would have helped improve health and contraceptive services. 
During the first fertility transition there was a fairly stable traditional gender division of labour. Husbands were supposed to be the sole breadwinner. Women's paid work was normally expected to end on marriage, and there were bars to employing married women in many occupations. For the first four decades of the twentieth century (apart from World War 1), the economic activity rate of married women was around one in ten, well below that of non-married women (two- thirds), let alone that of their husbands, ( well over 9 in 10 ). The sole breadwinner was the norm for which Beveridge designed the National Insurance system (Beveridge, 1942). Normally the male breadwinner would support the 'vital' unpaid work in the home by his wife. Her 'other duties', included the reproduction and maintenance of the population. Though a middle class ideal rather than working class reality, the implication was that increased female participation in production might jeopardise reproduction. Of course the 'meal ticket for life' apparently offered by marriage depended on the husband's continued ability (and willingness) to share, before or after any breakdown of the partnership. The increasing unreliability of marriage in the 'Second Demographic Transition' (Van der Kaa, 1987) added impetus to women maintaining independent contact with the labour market, in the later twentieth century.

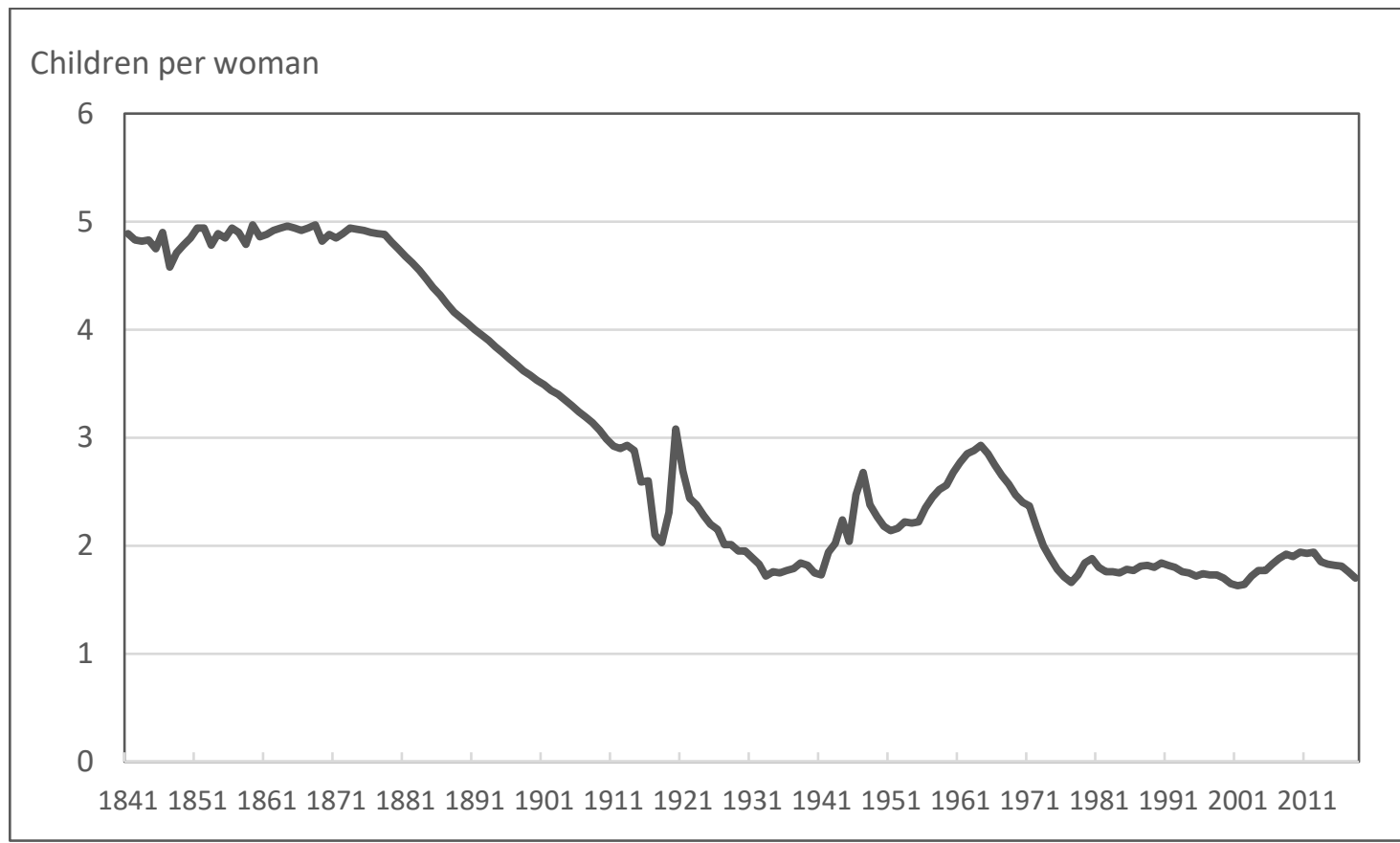

Figure 4. Total Period Fertility Rates in England +Wales 1841-2018

Patterns of Women's Employment in Britain

During the fertility decline era, education levels were very modest for most people, particularly women, over half of whom had no formal qualifications until those born after the Second War. Men preceded them into colleges, but by the end of the twentieth century, women had overtaken men in both school and tertiary qualifications.

Women's economic activity started a sustained upward trend, mostly among the married, in the post (second) war period. By the latest estimates from the Labour Force Survey in 2019, economic activity of married women (76\%) approached that of non-married women (79\%) and 85\% for men (Bryson, Joshi, Wielgoszewska and Wilkinson, 2020). Among wives born after about 1920, more continued in paid work between marriage and their first birth. After the war, mothers started 'returning' to the labour market when their children were of secondary school age. During the following decades, the age of the children of working mothers came down, initially taking advantage of childcare effectively available from schools. Employment interruptions became shorter as more mothers continued in paid work thanks to the extension of maternity leave. By the new millennium, public support for nonmaternal childcare had also emerged. 
The rise of the 'working mother' was led in the 1950s by working class families, in some regions. They were overtaken by graduates by the 1980 s, and the social gradient reversed (Joshi, 1985). Another development post 2000 was that employment rates of single mothers, initially depressed by the lack of childcare and the benefit poverty trap, ceased to lag behind mothers in couples. The changed practice of the latter led to a revision of the expectation in the benefit system that single parenthood was a sufficient reason for not being able to earn.

The post-war growth in women's employment was qualitatively different from men's. Initially, between 1951 and 1981 the extra women's jobs were part-time, specifically designed to tap a new source of labour supply in a fully employed economy. The jobs, in factories, shops and offices, were mainly sex-segregated, with low skill requirements and particularly low paid per hour. Part-timers remain a substantial part of the female workforce (39\% in 2019) but the proportion of women in full-time jobs started to grow in the 1980s. There was still a pay gap compared to men (around $40 \%$ to the mid-1970s) which, though gradually closing since the mid-1970s, remains apparent four decades on.- 9\% of men's full time pay in 2019 - 17\% including part-timers (ONS 2019)

Recent Fertility Trends in Britain

The post war baby boom peaked in 1964 with a total period fertility rate approaching 3 children per woman (Figure 4). Peak cohort fertility was about 2.4 for women born in 1935. This resurgence was clearly not brought about by women staying at home. Quite the contrary, employment and births rose at the same time. The fact that most of the extra employment was part-time helps explain how mothers were drawn into employment. The drop in fertility since 1964 went along with continued rise in women's employment at all working ages, more of it full-time of women who had not yet had children. At this juncture it could be argued that equal opportunities legislation and improvements in women's education helped to drive fertility decline, or at least the postponement of first births (De Cooman, Ermisch, and Joshi, 1987). But not all demographers were convinced (Murphy, 1993; Ní Bhrolcháin and Beaujouan, 2014). It was also difficult to establish that female employment was driving fertility decline in other industrial countries (Bernhardt 1993)

\section{Effect of Motherhood on Earnings}

It was easier to establish that women's employment and incomes were affected by having children. Women's labour supply was constrained by the presence of children, but to a diminishing extent, as mothers 'juggled' parttime jobs rather than staying at home. The limited hours of work when they did so was another deduction on the earnings they would have had as childfree full-timers. Mothers' hourly wage might be lowered by missing experience and training, low bargaining power and being limited to local employment.

Having studied participation, hours and wages in the Women and Employment Survey of 1980, I made a hypothetical estimate of their combined impact on a woman's lifetime earnings (Joshi, Davies and Land, 1996). Mrs Typical turned out to forgo about half her potential gross earnings having two children rather than none. I was not suggesting she would forgo motherhood as a result, and had indeed had my first child while putting the idea together. The idea of an 'opportunity cost' was generally well received by non-economists, rather more as a description of women's actual experience than as an explanation for their fertility decisions. The estimates were elaborated, in more work with Hugh Davies and updated to 1994, for the Cabinet Office Women's Unit (Rake ed 2000). Figure 5, drawn from that report, is a picture of earning trajectories for a low skilled woman with various numbers of children. Although labour force attachment had moved on, this picture was not dissimilar to that of the 1980-based Mrs Typical. The hypothetical trajectory with two children involves an 8-year gap in paid work from her first child's birth, until her second child goes to school. She then does a spell in part-time, followed by a return to full-time employment (at age 40 ), when her pay is below what it would have been had she been continuously employed full-time. 


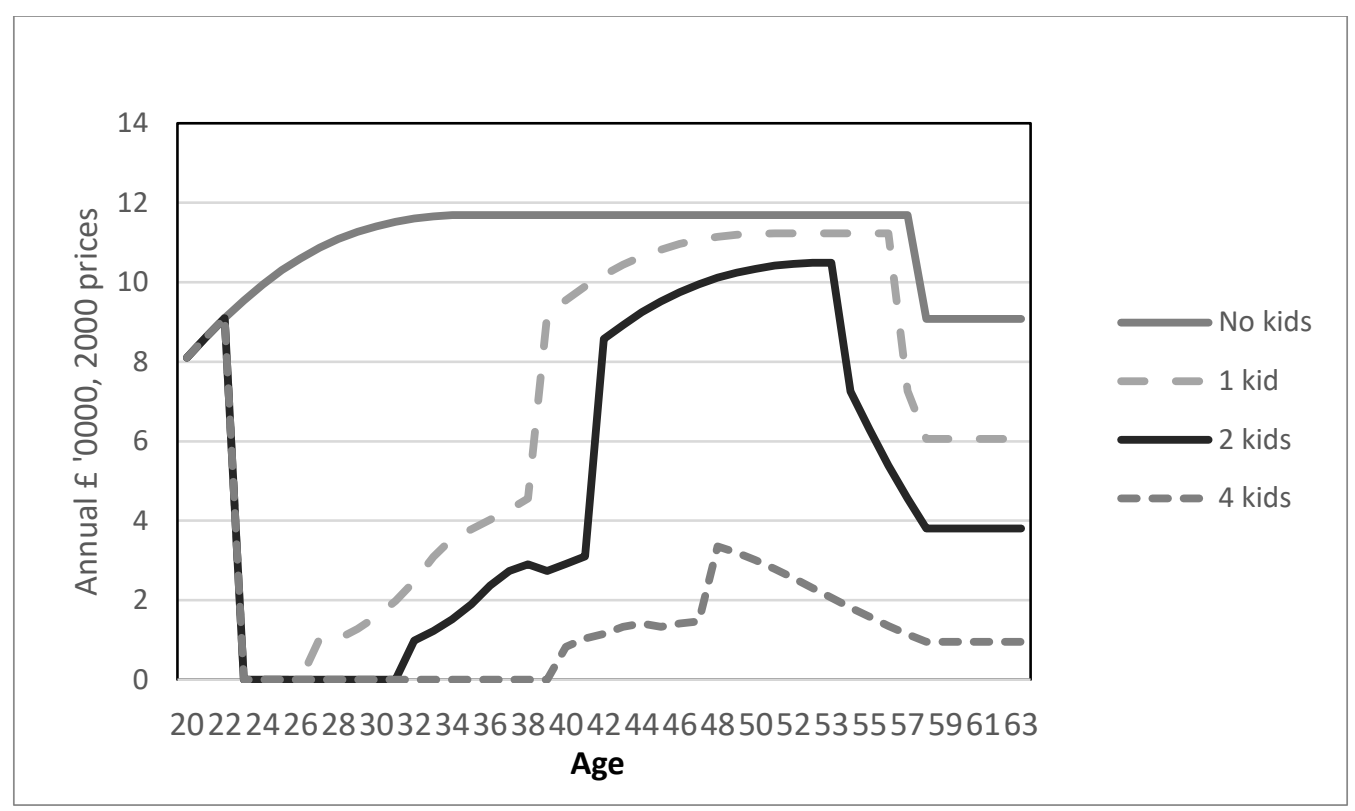

Figure 5. Earnings over a simulated lifetime, low skilled woman, by number of children.

The components of forgone earnings are shown on the left hand bar of Figure 6 . The biggest component here is the effect of working part-time hours. Almost as much is lost from a lower rate of pay due to work having been interrupted, the eight years of zero earning also make a sizable contribution in their own right. Many other illustrative cases were explored. Figure 6 summarizes the lost earnings in two more of them where the women had more qualifications: to a mid-skill level or to a high, graduate, level. . Earnings 'losses' were perhaps paradoxically less for women with more earning power. The mid-skill woman has a shorter interruption, but about as much earnings loss from working part-time. The high-skilled is simulated to manage employment continuity with minimal part-time interruptions (and paid childcare).

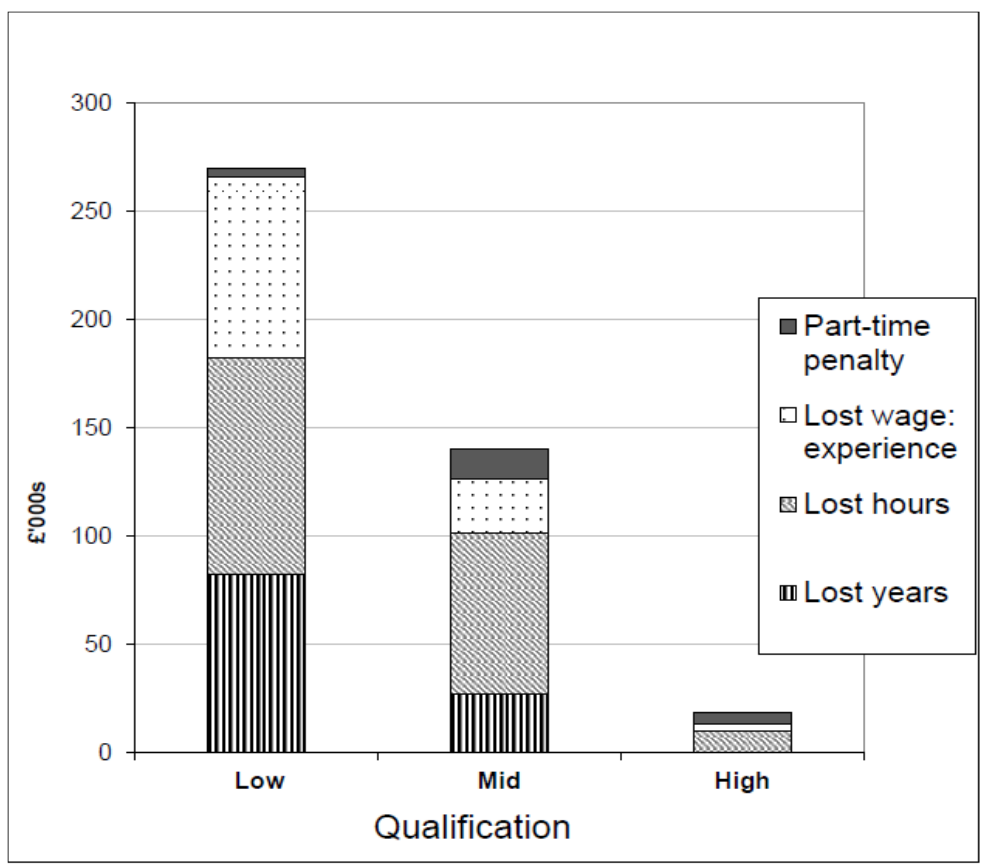

Figure 6. Woman's lifetime earnings forgone with 2 children, total and components, by skill level 
Rising women's employment entailed the shrinkage of Beveridge's sole male breadwinner from the norm to a minority. Especially with the growing instability of marriage, it was already apparent to Barbara Castle that women should normally expect to participate in the economy, not normally expect to be dependent on their husbands' social insurance. Her 1975 Social Security Act phased out the Married Women's Option, and introduced Home Responsibility pension credits for caring time out of paid work. It did not recognise the other sources of forgone earnings in low hours and low pay.

The earning forgone due to motherhood is compounded by the gap between what the person would have earned had they been a man rather than a woman. These are illustrated in Figure 7 for the individuals in the 1994-based model as the difference between the man's lifetime income and the childless woman's. These calculations assume (unrealistically) that the man's hours of work are no more than a childless woman's. Differences in pay per hour alone put the man's income noticeably ahead of the childless women's, let alone the mother's; in the mid and low skilled example. The male premium in wage rates creates the gap over the childless woman's earnings over and above the 'family gap' in women's wage rates considered above. It casts doubt on the idea that women's pay disadvantage has been reduced to the consequences of motherhood. Joshi (1991) made early estimates that mothers' wages in the 1970s were low not only because they were mothers, but also because they were female. Investigation of more recent gender pay gaps finds a male wage premium among the childless (Joshi, Bryson, Wilkinson and Ward, 2019)

The gender pay gap has dynamic implications. It makes it difficult for fathers to spend much time on childcare even with provisions for paternity leave. Interruptions damage the pay on return to employment of whoever takes them. There may be pay penalties to flexibility in work arrangements. If work and caring has to be 'juggled', that normally falls to the woman. Couples will tend to move home in pursuit of the better paid (usually male) career, whatever that implies for the 'trailing wife'. There is the pressure from unequal opportunities for pay and promotion in the labour market. The expectation or preference of women to take care of the children and others reinforces the woman's role-as the home-maker or secondary earner.

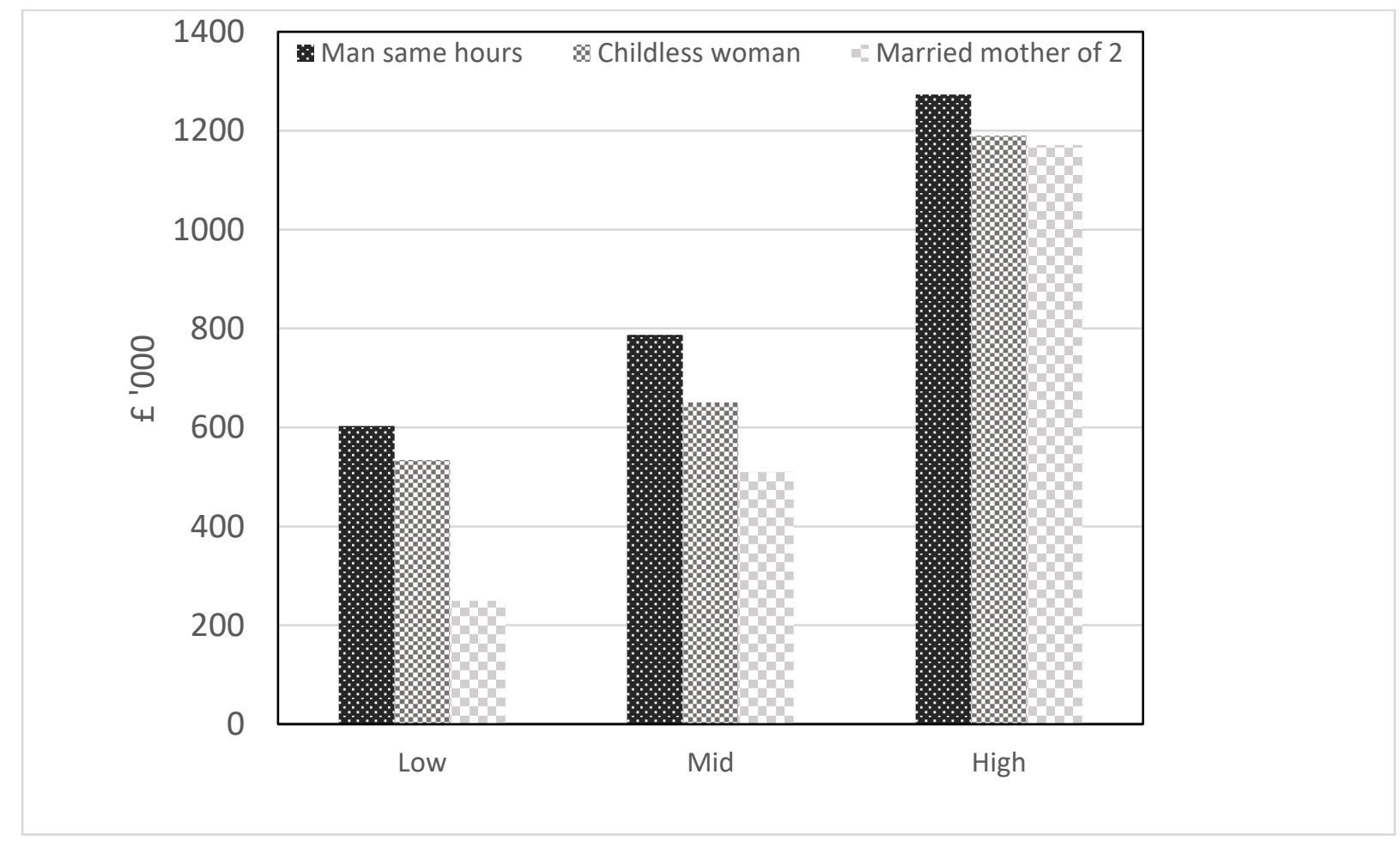

Figure 7. Total simulated lifetime earnings by gender and motherhood 
We pointed out that the 'losses' of women's earnings were not necessarily borne solely by the woman herself. If she was in a stable, sharing partnership, the couple would jointly bear the reduction in net income, which would also be shared in part by the tax and benefit system. We also pointed out that there are costs of parenthood other than gross earnings - in terms of sleep, leisure time and household production, as well as direct expenditure on goods and services for children by their parents and the state -and sometimes wear and tear on health.

The related question of whether children bore the cost of their mothers' employment was also addressed in a set of studies using longitudinal data on child development in UK and USA (summarised in Joshi, 2013). Despite the continued, but declining, belief that 'children suffer if their mother works in their pre-school years', there was little evidence to confirm it particularly after the millennium. The ideology surrounding the gender order seems to take a long time to change.

\section{Compatibility of Parenthood and Paid Work: Going Forward}

The potential conflict of motherhood and careers in Britain was resolved by compromises. The cash 'sacrificed' could be mitigated by various measures to improve their compatibility. These included flexibility on women's hours of employment, maternity leave and non-parental childcare. The latter became more acceptable in the UK recently. In the Scandinavian vanguard, policies to involve fathers in parental leave were included much earlier in 'family friendly' state provisions. Eva Bernhardt (1993) described the Scandinavian countries as following a 'combination strategy' to account for the paradox of countries with high female employment having the highest fertility rates in Europe. Ahn and Mira (2002) observed that the lowest fertility rates tended to occur in Southern European countries, which also had the lowest female employment rates. An explanation was the lack of opportunity of part-time employment in those countries, forming an obstacle to the combination strategy. Perhaps the less punishing costs of rearing the next generation, have made the UK relatively family-friendly, and its fertility by the twenty-first century is not among the lowest of the low.

In arguing that the 'opportunity cost of children was more than mothers' business' my Presidential Address to the European Society for Population Economics (Joshi 1998), I pointed out that fathers might be involved in the time costs of parenthood (although the paper seems to be erroneously cited as if it were about mothers). The possibility of fathers sharing in egalitarian parenting not only appears in the Cairo Declaration but also in influential work by Peter McDonald (2000) and Gøsta Esping-Andersen (2009). McDonald proposed a theory with of gender equality in two dimensions: One dimension based on the rights of an individual - such as equal pay - and dealing with an individual's family obligations. Equality in the individualistic dimension would tend to inhibit fertility, and the improvements in the other to promote it, through provisions such as employment flexibility, parental leaves, and public childcare. Esping-Andersen and Billari (2015) elaborate such a theory, presenting a U shaped trajectory of fertility, first falling as the 'female revolution' advances and then rising towards a new equilibrium in a state of mature gender egalitarianism. Sobotka. Matysiak and Brzozowska (2019) argue that 'incompatibility between professional career and family life' has been a main driver of low fertility, especially in societies with strong traditional gender role norms. Other factors contributing to fertility decline in their view are the trend towards intensive parenting, labour market uncertainty and instability and soaring housing prices.

There is evidence for such a story in Figure 8 comparing the fertility rates of EU countries in 2017 with the EU's Index of Gender Equality. The former is a crude summary of births in a country, allowing for women's ages, but nothing else (say social status, region or birth order). The Gender Equality Index is a sophisticated combination of indicators of gender differences in a number of domains: Work, Money, Knowledge, Time, Power and Health. These include gaps in time spent by men and women in caring activities as well a paid work, and the gender balance of parliamentarians (European Gender Institute, 2020). It is not the only such international index. 


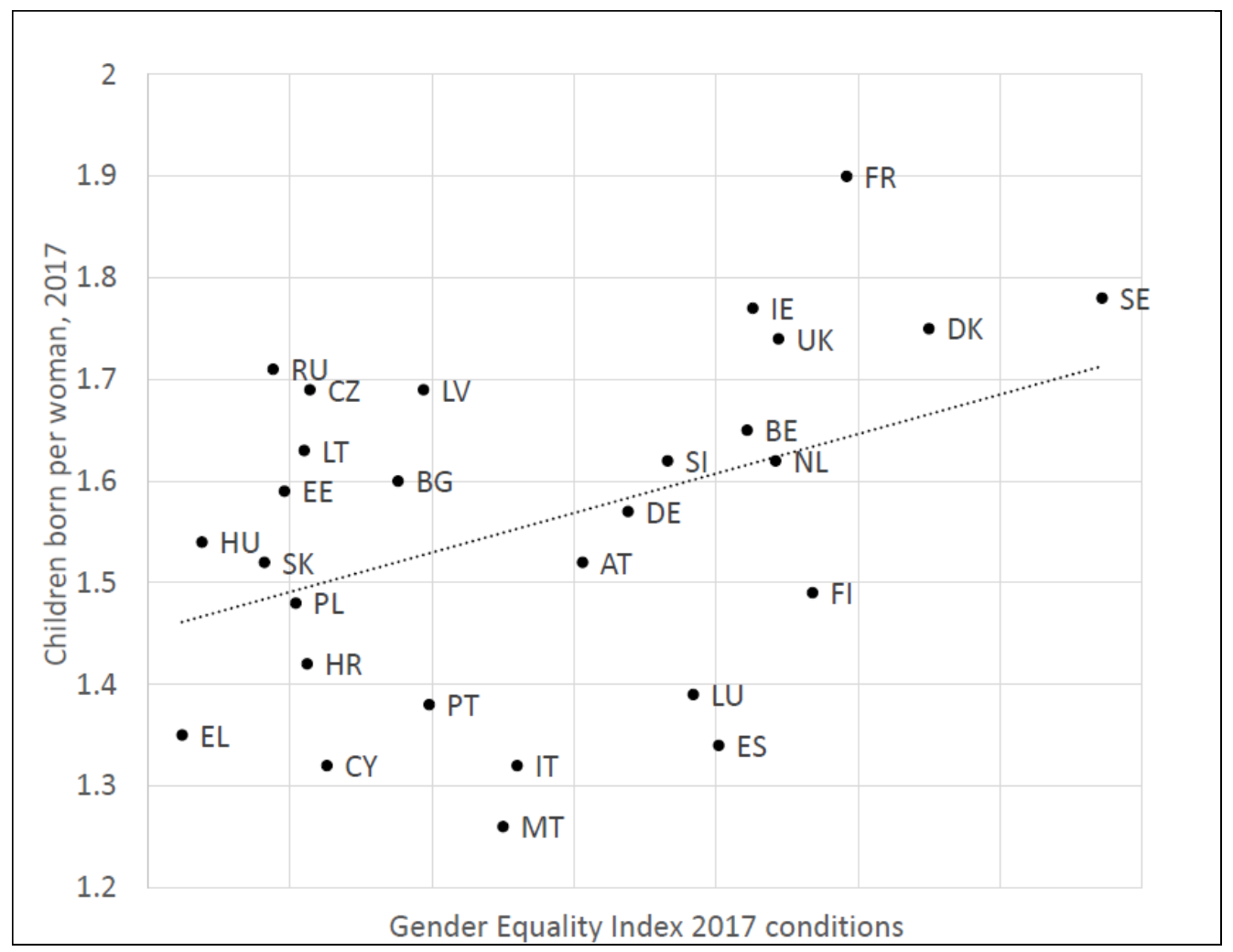

Figure 8. Total period fertility rates in EU countries, 2017, by their gender equality index

None of the fertility rates in 2017 are over 2, but it is the family friendly environments of northern Europe, particularly Scandinavia and France which have both the highest fertility and the highest Gender Equality. The lowest fertility is in some Southern European countries, which also show lower levels of gender inequality. This is only a correlation of crude national aggregates but it does suggest that gender equality is need not be incompatible with social reproduction. The details of how, where and for whom remain for gender researcher to tackle. As in the title of Esping-Andersen's book, the 'revolution' is unfinished.

\section{Conclusions}

To conclude: women's paid work does not necessarily lower their childbearing in either high or low fertility settings. The extent of any trade-off depends on gendered and socially diverse contexts. It does not seem to have been necessary to confine Britain's Mrs Typical to the home front to ensure that her 'vital duties' were performed, but the terms on which she joined the dual breadwinner workforce reflect both gender and social inequality. Motherhood does not necessarily lower a woman's earnings, although it has for many in Britain. The achievement of 'top jobs' and independence by some women, with or without children, does not apply across the board. Unequal pay of men and women before parenthood exacerbates the pay differentials experienced thereafter. The diversity of family arrangements, and the role of fathers within them, deserve acknowledgement and facilitation. Women may have 'come a long way' since the days of my untypical ancestors, but a gender- equitable balance of work and life, of production and reproduction, still has a way to go. Egalitarian parenthood may take an increasing number of forms in the $21^{\text {st }}$ century, but has the potential to provide better prospects for the reproduction and nurture of next generation.

\section{Acknowledgement:}

Current research on the Gender Pay Gap is funded by ESRC grant number ES/S012583/1). 


\section{References}

Ahn, N. and Mira P.(2002). "A note on the changing relationship between fertility and female employment rates in developed countries," Journal of Population Economics, 15:pp 667-682

Anker, R.(1982) Demographic Change and the Role of Women. In R Anker, M Buvinic and N.H Toussef (eds) Women's Roles and Population Trends in the Third World. Croom Helm for ILO pp 29-51.

Bernhardt, E.M.(1993) Fertility and Employment. European Sociological Review, 9, 1, pp25-42

Beveridge, W. (1942) Social Insurance and Allied Services (Cmd. 6404),

Bryson, A., Joshi, H., Wielgoszewska. B and Wilkinson D (2020) A Short History of the Gender Wage Gap in Britain. IZA Discussion paper 13289 ftp.iza.org/dp13289.pdf

Coleman, D. and J. Salt, J. (1992) The British Population: patterns, trends and processes. Oxford: Oxford University Press.

De Cooman, E., Ermisch, J., and Joshi, H. (1987). The Next Birth and the Labour Market: a Dynamic Model of Births in England and Wales. Population Studies, 41 (2), 237-268

Esping-Andersen, G (2009). The Incomplete Revolution: Adapting to Women's New Roles. Cambridge: Polity Press.

Esping-Andersen, G. and. Billari, F. C.( 2015). Re-theorizing family demographics, Population and Development Review 41(1)pp1-31

European Institute for Gender Equality (2020) Gender Equality Index. https://eige.europa.eu/gender-equalityindex/2019, Vilnius

Gavron, H (1966) The Captive Wife: Conflicts of Housebound Mothers. London: Routledge.

Hoem, B, Hoem, J. (1989) The Impact of Women's Employment on Second and Third Births in Modern Sweden, Population Studies, 43; pp 47-67.

Joshi, H. E. (1985) 'Motherhood and Employment: Change and Continuity in Post-war Britain' in Measuring SocioDemographic Change, Occasional Paper No 34, London: OPCS, 70-87.

Joshi, H. E. (1991) 'Sex and Motherhood as Sources of Women's Economic Disadvantage' in D. Groves and M. Maclean (Eds.) Women's Issues in Social Policy, London: Routledge, pp 179-193.

Joshi, H. (1998) 'The opportunity costs of childbearing: more than mothers' business' Journal of Population Economics, 11, pp 161-183.

Joshi, H. (2013) The Myth of the Working Mother: evidence from Longitudinal data. Research Brief 70 https://discovery.ucl.ac.uk/id/eprint/10018685/1/RB70_Myth_of_working_mother_Joshi.pdf

Joshi, H., Davies, H. and Land, H. (1996) The Tale of Mrs Typical, , London: Family Policy Studies Centre.

Joshi, H., Bryson, A., Wilkinson, D., Ward, K. (2019) The Gender Gap in Wages over the Life Course: Evidence from a British Cohort Born in 1958. IZA Discussion Paper. 12725, Bonn: Institute of Labor Economics.

Kirk, D. (1996) Demographic Transition Theory. Population Studies, 50, 3, pp 361-387

McDonald, P. (2000) Gender Equity in Theories of Fertility: Population and Development Review, Vol. 26, 3, pp. 427-439

Murphy M (1993). The Contraceptive Pill and Women's Employment as Factors in Fertility Change in Britain 19631980: A Challenge to the Conventional View, Population Studies, 47:2, 221-243, 
Ní Bhrolcháin, M. and Beaujouan, E. (2014) "Fertility postponement is largely due to rising educational enrolment", Population Studies, 66, 3: 311-327

Office of National Statistics (2019) Gender Pay Gap in the UK

https://www.ons.gov.uk/employmentandlabourmarket/peopleinwork/earningsandworkinghours/bulletins/gender paygapintheuk/2019

Piepmeier, K.P.and Adkins,T.S.(1973) The status of women and fertility. Journal of Biosocial Science 5, 4, pp507-520

Presser, H.B. (1997) Demography, Feminism, and the Science-Policy Nexus

Population and Development Review, Vol. 23, No. 2 (Jun., 1997), pp. 295-331

Rake, K. (ed) (2000) Women's Incomes over the Lifetime: a report to the Cabinet Office. HMSO

Sobotka, T., Matysiak. A. and Brzozowska, Z. (2020) Policy responses to low fertility: How effective are they?

Technical report to United Nations Population Fund

United Nations Population Fund (2014) Programme of Action of the International Conference on Population Development 20th Anniversary Edition, New York: UN

https://www.unfpa.org/sites/default/files/pub-pdf/programme of action Web\%20ENGLISH.pdf

Van der Kaa, D. (1987) Europe's Second Demographic Transition Population Bulletin, 42, Washington

World Data Atlas (2020) https://knoema.com/atlas/India 